\title{
The effect of increased frequency of hemodialysis on vitamin C concentrations: an ancillary study of the randomized Frequent Hemodialysis Network (FHN) daily trial
}

\author{
Jochen G. Raimann ${ }^{1 *}$ (D), Samer R. Abbas ${ }^{1}$, Li Liu ${ }^{1,2,3,4}$, Brett Larive ${ }^{5}$, Gerald Beck ${ }^{5}$, Peter Kotanko ${ }^{1,6}$,
} Nathan W. Levin ${ }^{1,6}$, Garry Handelman ${ }^{7}$ and the FHN Trial

\begin{abstract}
Background: Reports on vitamin C in HD patients have shown effects of vitamin C deficiency in association with scurvy symptoms. Dialyzability of water soluble vitamins is high, and substantial losses in those who are dialyzed more frequently were hypothesized. The randomized FHN Daily Trial compared the effects of in-center HD six versus three times per week. We studied baseline correlations between vitamin C and potentially associated parameters, and the effect of more frequent HD on circulating vitamin C concentrations.

Methods: We studied vitamin C levels at baseline and months, 3, 5 and 11. Patients enrolled between 2007 and 2009 into the randomized FHN Daily trial in the East Coast consortium were approached for participation. Predialysis plasma samples were processed with metaphosphoric acid and frozen at $-70^{\circ} \mathrm{C}$ for measurement with HPLC. Regression models between baseline log-transformed vitamin $C$ and hemoglobin, CRP, eKt $N$, ePCR and PTH, and a linear mixed-effects model to estimate the effect size of more frequent HD on plasma vitamin C, were constructed.

Results: We studied 44 subjects enrolled in the FHN Daily trial (50 \pm 12 years, 36\% female, 29\% Hispanics and 64\% blacks, $60 \%$ anuric). Vitamin $C$ correlated significantly with predialysis hemoglobin $(r=0.3 ; P=0.03)$ and PTH $(r=-0.3, P=0.04)$, respectively. Vitamin $C$ did not significantly differ at baseline (6x/week, $25.8 \pm 25.9$ versus $3 \times /$ week, $32.6 \pm 39.4 \mu \mathrm{mol} / \mathrm{L})$ and no significant treatment effect on plasma vitamin C concentrations was found $[-26.2(95 \% \mathrm{Cl}-57.5$ to 5.1$) \mu \mathrm{mol} / \mathrm{L}$ at Month 4 and - 2.5 (95\%Cl -15.6 to 10.6) $\mu \mathrm{mol} / \mathrm{L}$ at Month 12.

Conclusions: Based on data from this large randomized-controlled trial no significant effect of the intervention on circulating plasma vitamin C concentrations was found, allaying the concerns that more frequent HD would affect the concentrations of water-soluble vitamins and adversely affect patient's well-being. Correlations between vitamin $C$ and hemoglobin and PTH support the importance of vitamin $C$ for normal bone and mineral metabolism, and anemia management.
\end{abstract}

Keywords: Frequent hemodialysis network (FHN), Hemodialysis, Clinical trials, Left ventricular mass, Physical health component score, More frequent hemodialysis, Vitamin C

\footnotetext{
* Correspondence: Jochen.Raimann@rriny.com

${ }^{1}$ Renal Research Institute, 315 East 62nd Street, 4th Floor, New York, NY

10065, USA

Full list of author information is available at the end of the article
}

(c) The Author(s). 2019 Open Access This article is distributed under the terms of the Creative Commons Attribution 4.0 International License (http://creativecommons.org/licenses/by/4.0/), which permits unrestricted use, distribution, and reproduction in any medium, provided you give appropriate credit to the original author(s) and the source, provide a link to the Creative Commons license, and indicate if changes were made. The Creative Commons Public Domain Dedication waiver (http://creativecommons.org/publicdomain/zero/1.0/) applies to the data made available in this article, unless otherwise stated. 


\section{Background}

Low plasma levels of vitamin $\mathrm{C}$ have been documented in some hemodialysis patients for many years, and levels sometimes decrease to the range associated with scurvy (ca 1-2 $\mu \mathrm{mol} / \mathrm{L})$ [1]. This has led to the recommendation for use of moderate doses of supplements, which are prescribed in some patients [2].

What is the cause of these low levels? The most common vitamin C-rich foods, citrus and strawberries, also contain abundant potassium or oxalate [3], and are strictly limited in diets prescribed by renal dietitians [4]. Compliant patients have very low intake of such foods, which provide much of the vitamin $C$ in the American diet. Although supplements are often prescribed, the dose of the supplement is usually limited to $60-100 \mathrm{mg} /$ day, because of concern of conversion of excess vitamin $\mathrm{C}$ to oxalate (and subsequent calcium-oxalate deposition in soft tissue), and clinicians are conservative with use of supplemental vitamin $C$. Inflammation may be a factor causing low vitamin $\mathrm{C}$ levels and deficiency has been observed in patients with normal renal function during acute illness [5-8].

The dialysis process itself must be considered; during hemodialysis, vitamin $C$ is readily cleared, because it is a soluble, low-MW substance, and amounts of $50 \mathrm{mg}$ or greater can be removed by a single treatment [9]. Plasma vitamin $C$ at the end of a single treatment is typically decreased by two-thirds, in parallel with urea and creatinine [10]. The high dialytic clearance of vitamin C has led to the hypothesis that the treatment itself could be the primary cause of low vitamin $C$ levels.

More frequent dialysis could achieve even greater removal of vitamin $\mathrm{C}$, and lead to a more severe deficient state. This is of concern because low vitamin $\mathrm{C}$ is linked with difficulties in management of renal anemia [1] and may also be associated with other negative outcomes, possibly increasing the increased risk of mortality $[11,12]$.

Although there have been several trials of more frequent or prolonged hemodialysis [13, 14], there has been no examination of the effects of this modality on plasma vitamin C levels. We report here on plasma vitamin $C$ levels and its changes in a group of patients treated $6 \times /$ week with short daily $\mathrm{HD}$ in the Frequent Hemodialysis Network Daily Trial, compared with controls. As a secondary outcome, we examined vitamin $\mathrm{C}$ in relation to hemoglobin levels, C-reactive protein (CRP), and parathyroid hormone levels (PTH).

\section{Methods}

\section{Study design, setting and participants}

The FHN Daily Trial (http://www.clinicaltrials.gov \#NCT00264758) enrolled from $01 / 2006$ to $03 / 2010$, and patients enrolled during $07 / 2006$ to $03 / 2010$ at nine of the participating centers (listed in Appendix/
Recruitment sites) were approached for participation in this ancillary study to the main trial. A detailed overview of the trial design, the inclusion and exclusion criteria and randomization of the main trial has been published [15]. The study was approved by the Institutional Review Board of Beth Israel Medical Center and was conducted according to the Declaration of Helsinki. All patients signed informed consent.

This ancillary study aimed to recruit all patients that were enrolled as subjects during the entire active study period into the prospective, randomized, controlled FHN Daily Trial. Patients enrolled in the main trial were randomized on a facility level to receive either more frequent (6 times per week) or a conventional (3 times per week) HD regimen. The two co-primary outcomes of the main trial were the composite between mortality and left ventricular mass reduction and change in Physical Health Component score as per Short Form-36, respectively. All subjects recruited in the East Coast consortium were approached for recruitment for our ancillary study studying vitamin $\mathrm{C}$ concentrations throughout the course of the study. Due to the randomization on a facility basis in the main trial and our approaching of all patients enrolled in the main trial, the study population of this ancillary study can be considered as being virtually randomized to treatment arm allocation.

\section{Measurements}

Baseline demographic parameters were obtained in the FHN Daily Trial at baseline. Information on vitaminsupplements were assessed at baseline and monthly into the study. Hemoglobin, CRP, blood urea nitrogen and PTH were collected as per protocol of the main trial. Equilibrated non-normalized protein catabolic rate, equilibrated per session and weekly standard Kt/V were computed as per the FHN Daily Trials protocol. Physical Health Composite was assessed according to the Short Form-36 administered following the protocol of the main trial. Vitamin $\mathrm{C}$ samples were collected prior to a mid-week treatment coinciding at baseline, months 3, 5 and 11. After collection, plasma samples were processed with metaphosphoric acid and frozen at $-70{ }^{\circ} \mathrm{C}$ for measurement with high-performance liquid chromatography [16] at the study laboratory (University of Massachusetts, Lowell, USA).

\section{Statistical analyses}

Vitamin $C$ as the parameter of primary interest was analyzed as a continuous variable (natural log-transformed due to skewness) and dichotomized as deficient/non-deficient as per a threshold of $10 \mu \mathrm{mol} / \mathrm{L}$ [17]. All reported $p$-values are 2-sided without adjustments for multiple comparisons. $P$-values were considered significant when 
below 5\%. We conducted all analyses using SAS version 9.2 (SAS Institute, Cary, NC).

\section{Comparative analysis}

For the comparison between changes in parameters over time and the quantification of the treatment effect of the intervention we employed linear mixed-effects models adjusted for the baseline values of the studied parameter, which allowed us to estimate the effect size of more frequent HD on plasma vitamin C. Due to the limited sample size we refrained from additional adjustments of the models as done in the main trial.

\section{Correlational analysis}

Pearson and Spearman regression models between baseline $\log$-transformed vitamin $\mathrm{C}$ and hemoglobin, CRP, eKt/V, ePCR and PTH, were constructed for both the 3 times and 6 times per week group, and for the overall cohort.

\section{Results}

We studied 44 subjects enrolled in the FHN Daily trial (50 \pm 12 years, 36\% female, 29\% Hispanics and 64\% blacks, $60 \%$ anuric; see Table 1 for detailed demographics) from $07 / 2006$ to $03 / 2010$ and, of those, we were able to follow 30 until the end of the study (13 controls and 17 in the intervention group). There were no relevant

Table 1 Demographics and clinical parameters of included subjects

\begin{tabular}{|c|c|c|c|c|c|c|}
\hline \multicolumn{7}{|c|}{ Baseline characteristics of Daily Trial participants with vitamin C measures } \\
\hline \multirow[b]{2}{*}{ Characteristic } & \multicolumn{2}{|c|}{ All $(N=44)$} & \multicolumn{2}{|c|}{$\begin{array}{l}\text { Conventional Hemodialysis } \\
(N=20)\end{array}$} & \multicolumn{2}{|c|}{$\begin{array}{l}\text { Frequent Hemodialysis } \\
(N=24)\end{array}$} \\
\hline & $\begin{array}{l}\mathrm{N} \\
\text { Missing }\end{array}$ & mean +/-SD & N Missing & $\mathrm{a}$ & N Missing & $\mathrm{a}$ \\
\hline Age (yrs.) & 0 & $49.6 \pm 12.1$ & 0 & $50.6 \pm 11.9$ & 0 & $48.8 \pm 12.4$ \\
\hline Female sex (\%) & 0 & $16(36 \%)$ & 0 & $7(35 \%)$ & 0 & $9(38 \%)$ \\
\hline Hispanic ethnicity (\%) & 2 & $12(29 \%)$ & 2 & $3(17 \%)$ & 0 & $9(38 \%)$ \\
\hline Race & 0 & & 0 & & 0 & \\
\hline Black White Native American & & $28(64 \%)$ & & $14(70 \%)$ & & $.14(58 \%)$ \\
\hline Aboriginal Canadian & & $4(9 \%)$ & & 0 & & $4(17 \%)$ \\
\hline Alaskan Native & & $3(7 \%)$ & & $2(10 \%)$ & & $1(4 \%)$ \\
\hline First Nation Asian Native Hawaiian & & $2(5 \%)$ & & $1(5 \%)$ & & $1(4 \%)$ \\
\hline Other Pacific Islander & & $1(2 \%)$ & & $1(5 \%)$ & & 0 \\
\hline Other/mixed/unknown & & $6(14 \%)$ & & $2(10 \%)$ & & $4(17 \%)$ \\
\hline Duration of end-stage renal disease (\%) $<2 \mathrm{yr} .2-5 \mathrm{yr} .>5 \mathrm{yr}$ & 11 & $\begin{array}{l}.12(36 \%) 15(45 \%) \\
6(18 \%)\end{array}$ & 4 & $\begin{array}{l}.7(44 \%) \\
9(56 \%) 0\end{array}$ & 7 & $\begin{array}{l}.5(29 \%) 6(35 \%) \\
6(35 \%)\end{array}$ \\
\hline Diabetes (\%) & 0 & $13(30 \%)$ & 0 & $6(30 \%)$ & 0 & $7(29 \%)$ \\
\hline $\begin{array}{l}\text { Residual kidney function (\%) Anuria }>0 \text { to } 1 \mathrm{ml} / \mathrm{min} \\
>1 \text { to } 3 \mathrm{ml} / \mathrm{min}\end{array}$ & 0 & $\begin{array}{l}.26(59 \%) 9(20 \%) \\
9(20 \%)\end{array}$ & 0 & $\begin{array}{l}.6(30 \%) 5(25 \%) \\
9(45 \%)\end{array}$ & 0 & $\begin{array}{l}.20(83 \%) \\
4(17 \%) 0\end{array}$ \\
\hline Equilibrated per session Kt/N urea & 0 & $1.44 \pm 0.20$ & 0 & $1.46 \pm 0.22$ & 0 & $1.43 \pm 0.19$ \\
\hline Predialysis albumin (g/dL) & 0 & $4.12 \pm 0.34$ & 0 & $4.15 \pm 0.36$ & 0 & $4.09 \pm 0.32$ \\
\hline Predialysis sodium (mEq/L) & 0 & $139 \pm 3$ & 0 & $140 \pm 3$ & 0 & $139 \pm 3$ \\
\hline Predialysis potassium (mEq/L) & 0 & $4.92 \pm 0.59$ & 0 & $4.83 \pm 0.47$ & 0 & $4.99 \pm 0.68$ \\
\hline Predialysis calcium (mg/dL) & 0 & $9.35 \pm 0.74$ & 0 & $9.51 \pm 0.83$ & 0 & $9.22 \pm 0.65$ \\
\hline Predialysis hemoglobin (mg/dL) & 0 & $12.1 \pm 1.3$ & 0 & $12.4 \pm 1$ & 0 & $11.8 \pm 1.4$ \\
\hline Predialysis Parathyroid hormone (pg/mL) & 0 & $408[283,927]$ & 0 & $389[246,1039]$ & 0 & $471[289,927]$ \\
\hline Physical Health Composite score & 0 & $40.3 \pm 11.0$ & 0 & $39.7 \pm 9.6$ & 0 & $40.9 \pm 12.2$ \\
\hline Mental Health Composite score & 0 & $47.6 \pm 12.4$ & 0 & $45.8 \pm 10.1$ & 0 & $49.1 \pm 14.0$ \\
\hline Iron administration (Y/N) & 0 & $1(2 \%)$ & 0 & $1(5 \%)$ & 0 & 0 \\
\hline Erythropoiesis-Stimulating Agents (EPO equivalent units) & 0 & $\begin{array}{l}9250 \\
{[3138,22,875]}\end{array}$ & 0 & $\begin{array}{l}8750 \\
{[2913,27,625]}\end{array}$ & 0 & $\begin{array}{l}9250 \\
{[3138,19,750]}\end{array}$ \\
\hline Left Ventricular Mass (g) & 0 & $166 \pm 65$ & 0 & $179 \pm 66$ & 0 & $155 \pm 63$ \\
\hline CRP $(\mathrm{mg} / \mathrm{dL})$ & 10 & $\begin{array}{l}0.362 \\
{[0.221,0.964]}\end{array}$ & 4 & $\begin{array}{l}0.412 \\
{[0.242,0.986]}\end{array}$ & 6 & $\begin{array}{l}0.362 \\
{[0.221,0.932]}\end{array}$ \\
\hline
\end{tabular}

aplus-minus values are means \pm SD. Bracketed values are medians with interquartile ranges (chosen for skewness of data as per visual inspection of distribution) 


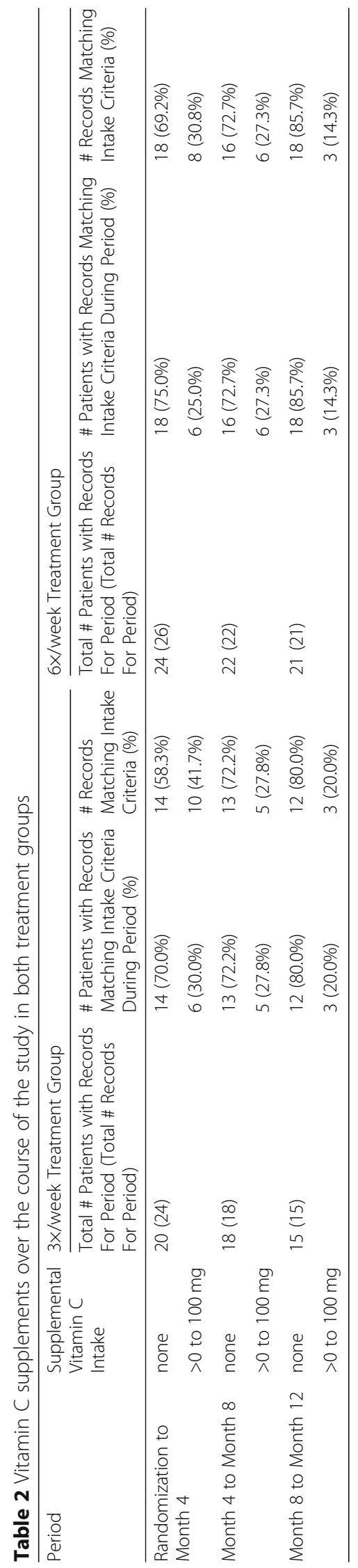




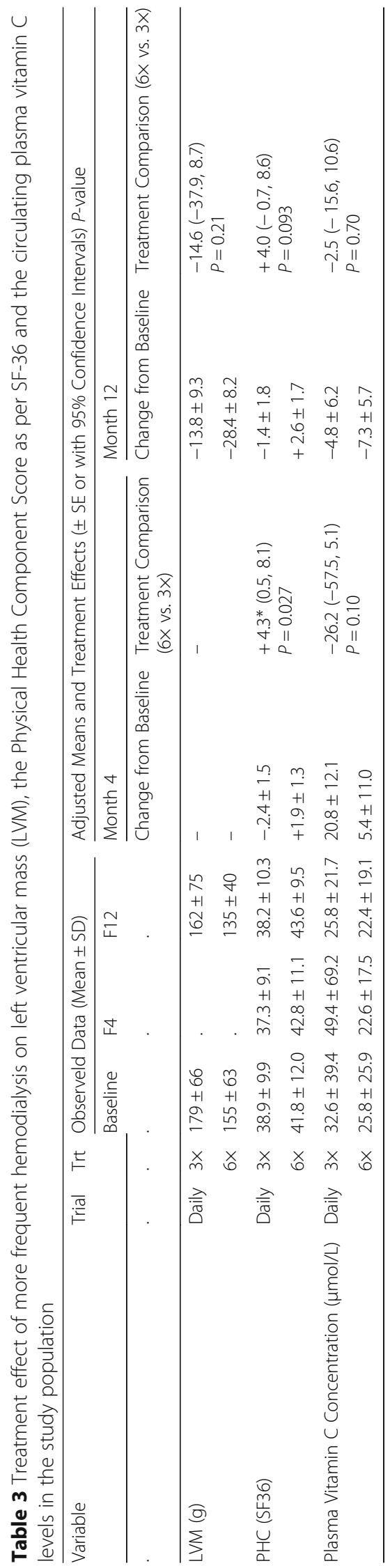




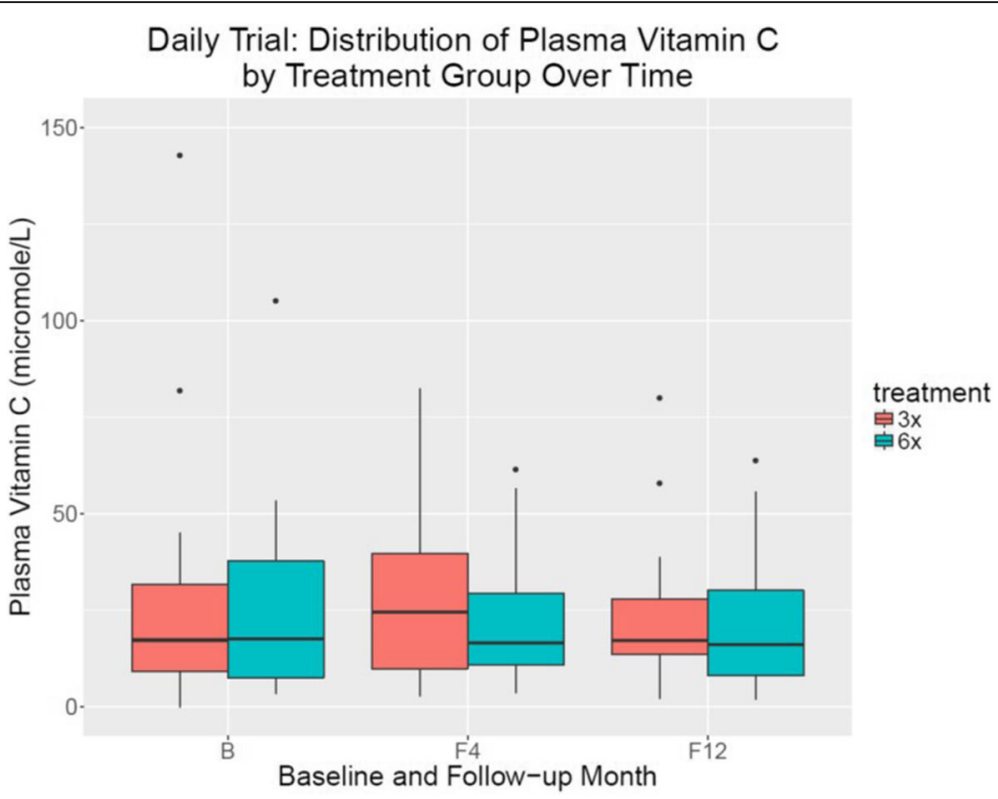

Fig. 1 Box-Whisker plot depicting the distribution of plasma vitamin C by treatment group over time in the study population

differences in vitamin $C$ supplementation in both groups at baseline and during the course of the study (Table 2). Vitamin $\mathrm{C}$ concentrations did not significantly differ at baseline (6×/week: $25.8 \pm 25.9 \mu \mathrm{mol} / \mathrm{L}$ versus $3 \times /$ week: $32.6 \pm 39.4 \mu \mathrm{mol} / \mathrm{L}$; Table 3 and Fig. 1). At study baseline we found 4 of these patients (31\%) to be vitamin C deficient as compared to $6(35 \%)$ in the intervention group. After 4 months into the study the fraction of vitamin C-deficient subjects decreased to 23 and 24\%, respectively, in the control and treatment arms. At 12 months the fraction in the control arm decreased to $8 \%$ as compared to $35 \%$ in the intervention arm (Table 4). However, differences between the groups and within the groups over time were not significant.

\section{Comparative analysis}

In line with the analysis of prevalence of vitamin $\mathrm{C}$ deficiency and its evolution over the course of the study we also did not find significant adjusted treatment effects on vitamin C concentrations [-26.2 (95\%CI -57.5 to 5.1$)$ $\mu \mathrm{mol} / \mathrm{L}$ at Month 4 and $-2.5(95 \% \mathrm{CI}-15.6$ to 10.6$) \mu \mathrm{mol} / \mathrm{L}$ at Month 12 (Table 3). While consistent with the results of the main trial in terms of reductions over time, the models constructed for Physical Health Component score and left ventricular mass did not show significant treatment effects

Table 4 Prevalence of vitamin C deficiency in the study population at different timepoints during the study period

\begin{tabular}{llll}
\hline Treatment Group & Baseline & Month 4 & Month 12 \\
\hline $3 \times$ per week & $4 / 13(31 \%)$ & $3 / 13(23 \%)$ & $1 / 13(8 \%)$ \\
6x per week & $6 / 17(35 \%)$ & $4 / 17(24 \%)$ & $6 / 17(35 \%)$ \\
\hline
\end{tabular}

of more frequent $\mathrm{HD}$ for those participating in this ancillary study, likely due to the low sample size (Table 3).

\section{Correlational analysis}

In Pearson correlation predialysis vitamin $C$ at baseline correlated significantly with those of predialysis hemoglobin (positive correlation; Spearman $r=0.3 ; P=0.03$ ) and PTH (negative correlation; Pearson $\mathrm{r}=-0.3, P=0.04$ ), respectively (Table 5; Fig. 2a and Fig. 2b). No associations were found between vitamin $\mathrm{C}$ concentrations and CRP, Physical Health Component score and equilibrated non-normalized protein catabolic rate. In line with the primary hypothesis tested, we also found no associations between predialysis vitamin $\mathrm{C}$ concentrations and equilibrated per session $\mathrm{Kt} / \mathrm{V}$ and weekly standard Kt/V (Table 5).

\section{Discussion}

\section{Statement of principal findings}

Based on data from our ancillary study from this large randomized-controlled trial, no significant treatment effect of the intervention on circulating plasma vitamin $\mathrm{C}$ concentrations and the prevalence of vitamin $\mathrm{C}$ deficient patients was found, allaying the concerns that more frequent hemodialysis would decrease the concentrations of water-soluble vitamins and adversely affect patients' well-being. Of great interest for future studies, however, are the reported correlations between vitamin $\mathrm{C}$ and hemoglobin and $\mathrm{PTH}$, respectively, that support the importance of vitamin $\mathrm{C}$ for normal bone and mineral metabolism and anemia management. 


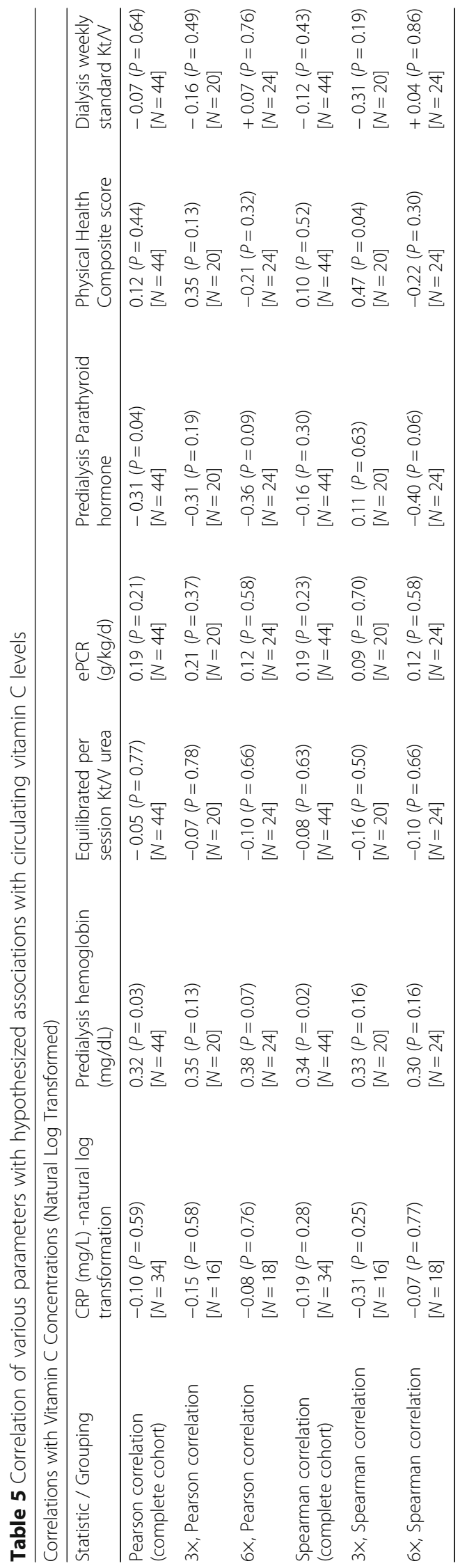



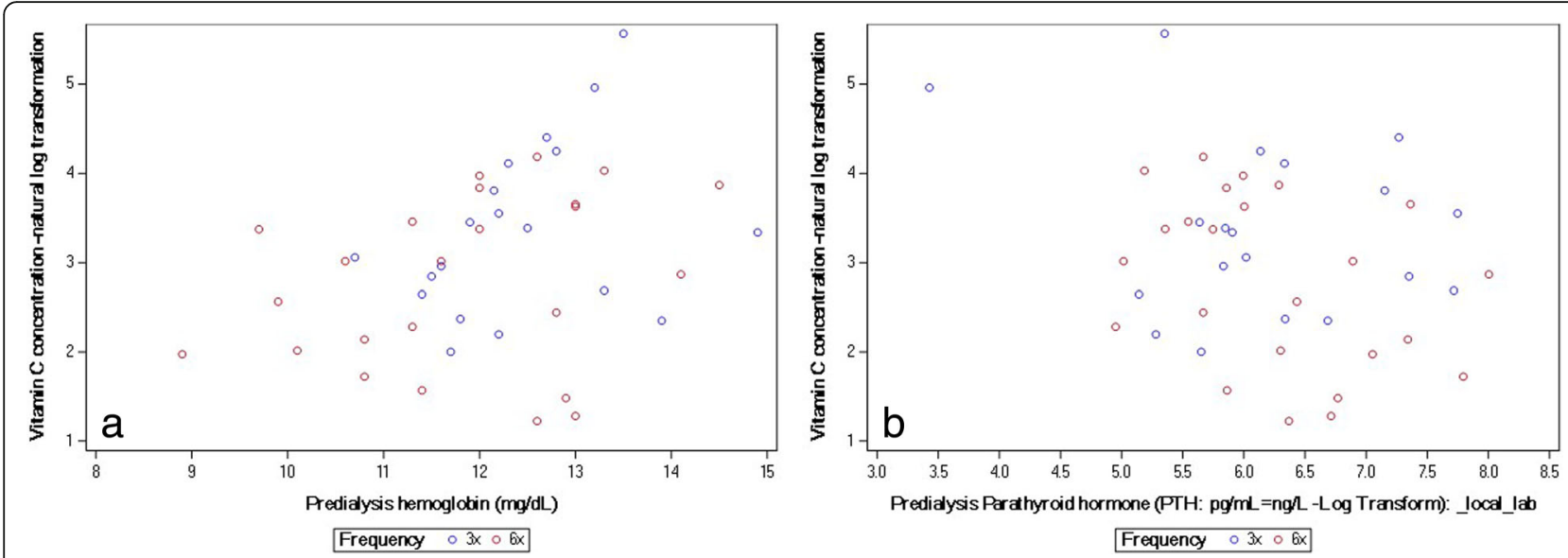

Fig. 2 Relationship between (natural log transformed) plasma vitamin C and pre-dialysis a) hemoglobin and b) (log transformed) parathyroid hormone

\section{Discussion in the light of other studies Treatment effect of more frequent hemodialysis and dialysis dose}

Morena and colleagues estimated the vitamin $\mathrm{C}$ diffusive flux at $271 \mu \mathrm{g} / \mathrm{min}$ and $66 \mathrm{mg}$ average loss per 4-h session which can be a substantial amount of loss with increased dialysis frequency [18]. Boehm and colleagues investigated the vitamin $\mathrm{C}$ status in hemodialysis patients and reported a $50 \%$ decrease in vitamin $\mathrm{C}$ associated with dialysis treatment. Despite substantially higher weekly delivered dialysis dose (weekly standard $\mathrm{Kt} / \mathrm{V}$ ) in the more frequent hemodialysis arm $(3.6 \pm 0.6$ versus $2.6 \pm 0.3)$ [13] in our data, there was no effect on circulating predialysis vitamin $\mathrm{C}$ levels (Table 3 and Fig. 1) and the prevalence of vitamin $\mathrm{C}$ deficiency (Table 3 ). This can be explained by adequate nutritional intake throughout the study and the fact that most vitamin $C$ is stored within the tissues which serve as a pool that refills the intravascular compartment from which dialysis removes compounds [19, 20].

\section{Associations between vitamin C and hemoglobin}

Vitamin $C$ plays a major role in iron metabolism facilitating storage and iron mobilization thus affecting the levels of biologically available iron needed for hematopoiesis [21]. Studies in dialysis patients have shown that vitamin C supplementation may lead to decreased serum ferritin levels [22], which is consistent with storage iron mobilization. These reports are supported by previously reported data from several studies [22-28] and confirmed in a recently published meta-analysis by Deved and colleagues [29]. Our data on the correlation between hemoglobin and vitamin $\mathrm{C}$ supports this association and the claims made by Deved and others on the importance of considering the prescription of vitamin $\mathrm{C}$ in anemia management (Fig. 2a and Table 5).

\section{Associations between vitamin C and PTH}

An inverse relationship between vitamin $\mathrm{C}$ and PTH is in line with data reported by Richter and colleagues [17], which showed an inverse relationship between vitamin $\mathrm{C}$ and PTH concentrations. The authors hypothesized an effect of vitamin $C$ on post-receptor events in the super-family of seven membrane spanning receptors [30], that include PTH receptors in the bone [31] and calcium-sensing receptors in the parathyroid gland [32]. Consistent with Richter et al.'s findings we also see an inverse relationship between the concentrations of these two compounds in our data (Fig. 2b and Table 5). The absence of alkaline phosphatase measurements in the data of the main trial did not allow the reproduction of that aspect of the study by Richter et al. [17].

\section{Associations between inflammatory markers}

Given the role of vitamin $\mathrm{C}$ as an antioxidant and scavenger of reactive oxygen species, we hypothesized a relationship between levels of vitamin $\mathrm{C}$ at baseline and of CRP that were collected as part of the protocol in the main trial, as was reported by another investigation [23]. In our data there was no clear relationship between CRP and vitamin $\mathrm{C}$, which, however, does not necessarily imply a lack of effect of vitamin $\mathrm{C}$ on oxidative stress and the (increased) level of inflammation in dialysis patients.

\section{Strengths and limitations}

While the sample size of our ancillary study is admittedly small, we have had the great advantage to follow recruitment and randomization on a facility basis of the main trial. Thus we claim that also our data can be considered quasi-randomized, minimizing confounding. However, recruitment only took place in the East Coast consortium, thus a possible lack of generalizability needs to be acknowledged that may limit the interpretation of 
our findings in different dialysis populations and for different practice patterns. A clear limitation of our analysis is the lack of dietary data and the lack of data in the West Coast consortium concerning supplements ingested by the studied patients. A good argument can, however, be made that diet and supplement intake have likely not changed during the study period and practices were balanced between the randomized groups.

\section{Conclusion}

We found a lack of treatment effect of more frequent hemodialysis treatments on circulating plasma vitamin $C$ concentrations and the prevalence of vitamin $C$ deficiency. This is of importance for the nephrologist when considering increased dialysis frequency, additional dialysis treatments or extended dialysis session lengths for patients. The associations between vitamin $\mathrm{C}$, and hemoglobin and $\mathrm{PTH}$, respectively, may be relevant when prescribing or recommending vitamin $\mathrm{C}$ to dialysis patients, particularly to those receiving higher dialysis frequency or additional treatments, and/or are being prescribed with higher dialysis doses per dialysis session. The effect on both parameters requires consideration of the overall recommendations on vitamin $\mathrm{C}$ in dialysis patients, given that current concerns on conversion of ascorbate into oxalate and subsequent deposit in various tissues (including vessel walls leading to accelerated arterial stiffening) are based on outdated and small case series and reports [33-38]. Large controlled trials are needed to determine the optimal approach for vitamin $\mathrm{C}$ supplementation in dialysis patients. It would be prudent to ensure that patients who received extended or more frequent dialysis be prescribed a standard regimen containing 60 or $100 \mathrm{mg}$ of vitamin C per day.

\section{Appendix}

\section{FHN Trial Group}

Chair, Steering Committee: Kliger A; NIDDK: Eggers P, Briggs J, Hostetter T, Narva A, Star R; Centers for Medicare and Medical Services: Augustine B, Mohr P; Data Coordinating Center - Cleveland Clinic: Beck G (PI), Fu Z, Gassman J, Greene T, Daugirdas J, Hunsicker L, Larive B, Li M, MacKrell J, Wiggins K, Sherer S, Weiss B; MRI Core - Ohio State University and Mt. Sinai Medical Center: Rajagopalan S, Sanz J, Dellagrottaglie S, Kariisa M; Tran T, West J; Central Quality of Life Core - University of Pittsburgh: Unruh M; Keene R, Schlarb J; Central Holter Core- Toronto General Hospital: Chan C; McGrath-Chong M; Biospecimen Repository - Fisher BioServices: Frome R, Higgins $\mathrm{H}$, Ke S, Mandaci O, Owens C, Snell C; Data Safety and Monitoring Board: Eknoyan G (Chair), Appel L, Cheung A, Derse A, Kramer C, Geller N, Grimm R, Henderson L, Prichard S, Roecker E;
Daily Trial Clinical Sites - University of California San Francisco (UCSF)/Stanford Consortium: Chertow G (PI); UCSF and San Francisco Bay Area: James S, Chertow G, Tamura M, Hall Y, McCulloch C, Painter P, Gorodetskaya I, Tichy M, Humphreys M, Luan J, Escalada R, Rodriquez R; UC Davis and Sacramento Area: Depner T, Kaysen G, Suter M, Sonico J, Anderson S; El Camino Hospital and Satellite Health Care: Ting G, Schiller B, Coplon N, Doss S, Rogers J, Dominguez A, Atwal J, Lemus D; UCLA and Los Angeles Area: Rastogi A, Nissenson A, Goodman W, Salusky I, Schweitzer S, Rivas M, Smith M, Gayda P, Hernandez A, Rashid M; UCSD and San Diego Area: Mehta R, Pepas J, Bharti B, Nabali A, Manaster R, Mathew R, Shah S, Sanz G, Wei J; University of Texas, San Antonio: Ayus J, Achinger S, Gutierrez M; Renal Research Institute (RRI) New York Consortium: Levin N (PI); Bay W, Carter M, Geronemus R, Kuhlmann M, Handelman G, Gotch F, Finkelstein F, Kimmel P, Lacson E, Ornt D, Greenwood R, Vassalotti J, Burrowes J; RRI New York City: Levin N, Kotanko P, Kaufman A, Winchester J, Meisels I, Radbill B, Chang J, Fofie Y, Ramos R, Sergeyeva O, Callegari J, Arthur B, Tarallo M, Ulloa D, Apruzzese R; University of Western Ontario: Lindsay R, Suri R, Garg A, Bullas R Mazzorato A; Wake Forest University School of Medicine: Rocco M, Burkart J, Moossavi S, Mauck V, Kaufman T, Coppley A; Vanderbilt University Medical Center: Schulman G, McLeroy S, Sika M, Leavell E; Barnes Jewish/Washington University: Miller B, Schussler R, Bardsley J, Skelton R.

Nocturnal Trial Clinical Sites - Wake Forest University School of Medicine Consortium: Rocco M (PI); Barnes-Jewish/Washington University: Miller B, Riley J, Schuessler R; Lynchburg Nephrology: Lockridge R, Pipkin M, Peterson C; Rubin Dialysis: Hoy C, Fensterer A, Steigerwald D; University of Iowa: Stokes J, Somers D, Hilkin A, Lilli K, Wallace W, Franzwa B, Waterman E; University of Toronto: Chan C, McGrath-Chong M; University of British Columbia: Copland M, Levin A, Sioson L, Cabezon E, Kwan S, Roger D; University of Western Ontario: Lindsay R, Suri R, Champagne J, Bullas R, Garg A, Mazzorato A, Spanner E; Wake Forest University School of Medicine: Rocco M, Burkart J, Moossavi S, Mauck V, Kaufman T; Humber River Regional Hospital: Pierratos A, Chan W, Regozo K, Kwok S.

\section{Recruitment sites}

Renal Research Institute Consortium: Irving Place Dialysis Center, Queens Artificial Kidney Center, South Queens Dialysis Center, Southern Manhattan Hemodialysis Center, St. Alban's Dialysis, Upper Manhattan Dialysis Center, Yorkville Dialysis Center.

\section{Abbreviations}

CRP: C-reactive protein; eKt/N: equilibrated Kt/N; ePCR: equilibrated Protein Catabolic Rate; FHN: Frequent Hemodialysis Network; HD: Hemodialysis; 
HPLC: High-performance liquid chromatography; NIDDK: National Institutes of Diabetes and Digestive and Kidney Diseases; NIH: National Institutes of Health; PTH: Parathyroid hormone; USA: United States of America

\section{Acknowledgements}

The authors wish to acknowledge and thank the entire Frequent Hemodialysis Network (FHN) Trials Group. Part of the data presented in this manuscript was presented as a poster presentation at Renal Week 2017 of the American Society of Nephrology in New Orleans, LA, USA.

\section{Funding}

The main trial was supported by the National Institutes of Health $(\mathrm{NIH})$, National Institutes of Diabetes and Digestive and Kidney Diseases (NIDDK), the Center for Medicare and Medical Services and the NIH Research Foundation. Contributors to the NIH Foundation in support of the FHN trials included Amgen, Baxter, and Dialysis Clinics. Additional support was provided by DaVita, Dialysis Clinics, Fresenius Medical Care, Renal Advantage, Renal Research Institute, and Satellite Healthcare. This ancillary study was funded and conducted and funded by the Renal Research Institute.

\section{Availability of data and materials}

The datasets used and/or analysed during the current study are available from the corresponding author on reasonable request.

\section{Authors' contributions}

GJH, NWL, PK and JGR have designed the ancillary study. The FHN Trial has recruited and studied the enrolled patients, and has further organized for the increase in dialysis frequency. JGR, SA and LL have conducted the study. JGR has managed the data collection and transfer to the Data Coordinating Center, BL and GB have conducted the analysis. All authors have contributed to the development and writing of the manuscript. All authors read and approved the final manuscript.

\section{Ethics approval and consent to participate}

This manuscript reports data from an ancillary study to the Frequent Hemodialysis Network (FHN) Daily Trial (http://www.clinicaltrials.gov \#NCT00264758). This ancillary study aimed to recruit all patients that were enrolled as subjects during the entire active study period into the prospective, randomized, controlled FHN Daily Trial.

The study was approved by the Institutional Review Board of Beth Israel Medical Center and was conducted according to the Declaration of Helsinki. All patients signed informed consent.

\section{Consent for publication}

Not applicable.

\section{Competing interests}

Peter Kotanko holds stock in Fresenius Medical Care North America. All other authors have nothing to disclose.

\section{Publisher's Note}

Springer Nature remains neutral with regard to jurisdictional claims in published maps and institutional affiliations.

\section{Author details}

'Renal Research Institute, 315 East 62nd Street, 4th Floor, New York, NY 10065, USA. ${ }^{2}$ Renal Division, Peking University First Hospital, Beijing, People's Republic of China. ${ }^{3}$ Key Laboratory of Renal Disease, Ministry of Health of China, Beijing, China. ${ }^{4}$ Key Laboratory of Chronic Kidney Disease Prevention and Treatment, Ministry of Education, Beijing, China. ${ }^{5}$ Cleveland Clinic Foundation, Cleveland, OH, USA. ${ }^{6}$ Icahn School of Medicine at Mount Sinai Health System, New York, NY, USA. ${ }^{7}$ University of Massachusetts Lowell, Lowell, MA, USA.

Received: 10 August 2018 Accepted: 25 March 2019 Published online: 17 May 2019

\section{References}

1. Raimann JG, Levin NW, Craig RG, Sirover W, Kotanko P, Handelman G. Is vitamin C intake too low in dialysis patients? Semin Dial. 2013;26(1):1-5.
2. Clase CM, Ki V, Holden RM. Water-soluble vitamins in people with low glomerular filtration rate or on dialysis: a review. Semin Dial. 2013;26(5):546-67.

3. Massey LK, Roman-Smith $H$, Sutton RA. Effect of dietary oxalate and calcium on urinary oxalate and risk of formation of calcium oxalate kidney stones. J Am Diet Assoc. 1993;93(8):901-6.

4. Clinical practice guidelines for nutrition in chronic renal failure. K/DOQI, National Kidney Foundation. Am J Kidney Dis. 2000;35(6 Suppl 2):S1-140.

5. Fain O, Paries J, Jacquart B, Le Moel G, Kettaneh A, Stirnemann J, Heron C, Sitbon M, Taleb C, Letellier E, et al. Hypovitaminosis C in hospitalized patients. European journal of internal medicine. 2003; 14(7):419-25.

6. Galley HF, Davies MJ, Webster NR. Ascorbyl radical formation in patients with sepsis: effect of ascorbate loading. Free Radic Biol Med. 1996;20(1):139-43.

7. Paz HL, Martin AA. Sepsis in an aging population. Crit Care Med. 2006;34(1):234-5.

8. Wilson JX. Evaluation of vitamin C for adjuvant sepsis therapy. Antioxid Redox Signal. 2013;19(17):2129-40.

9. Bohm V, Tiroke K, Schneider S, Sperschneider H, Stein G, Bitsch R. Vitamin C status of patients with chronic renal failure, dialysis patients and patients after renal transplantation. Int J Vitam Nutr Res. 1997;67(4):262-6.

10. Sirover WD, Liu Y, Logan A, Hunter K, Benz RL, Prasad D, Avila J, Venkatchalam T, Weisberg LS, Handelman GJ. Plasma ascorbic acid concentrations in prevalent patients with end-stage renal disease on hemodialysis. J Ren Nutr. 2015;25(3):292-300.

11. Dashti-Khavidaki S, Talasaz AH, Tabeefar H, Hajimahmoodi M, Moghaddam G, Khalili H, Lessan-Pezeshki M, Jahanmardi A. Plasma vitamin C concentrations in patients on routine hemodialysis and its relationship to patients' morbidity and mortality. Int J Vitam Nutr Res. 2011;81(4):197-203.

12. Deicher R, Ziai F, Bieglmayer C, Schillinger M, Horl WH. Low total vitamin C plasma level is a risk factor for cardiovascular morbidity and mortality in hemodialysis patients. J Am Soc Nephrol. 2005;16(6):1811-8.

13. Chertow GM, Levin NW, Beck GJ, Depner TA, Eggers PW, Gassman JJ, Gorodetskaya I, Greene T, James S, Larive B, et al. In-center hemodialysis six times per week versus three times per week. N Engl J Med. 2010;363(24):2287-300.

14. Thumfart J, Pommer W, Querfeld U, Muller D. Intensified hemodialysis in adults, and in children and adolescents. Deutsches Arzteblatt international. 2014;111(14):237-43

15. Suri RS, Garg AX, Chertow GM, Levin NW, Rocco MV, Greene T, Beck GJ, Gassman JJ, Eggers PW, Star RA, et al. Frequent hemodialysis network (FHN) randomized trials: study design. Kidney Int. 2007;71(4):349-59.

16. Wang S, Geraci G, Kuhlmann MK, Levin NW, Handelman GJ. Chemical reactions of vitamin C with intravenous-iron formulations. Nephrol Dial Transplant. 2008;23(1):120-5.

17. Richter A, Kuhlmann MK, Seibert E, Kotanko P, Levin NW, Handelman GJ. Vitamin $C$ deficiency and secondary hyperparathyroidism in chronic haemodialysis patients. Nephrol Dial Transplant. 2008;23(6):2058-63.

18. Morena M, Cristol JP, BosC JY, Tetta C, Forret G, Leger CL, Delcourt C, Papoz L, Descomps B, Canaud B. Convective and diffusive losses of vitamin $C$ during haemodiafiltration session: a contributive factor to oxidative stress in haemodialysis patients. Nephrol Dial Transplant. 2002;17(3):422-7.

19. Graumlich JF, Ludden TM, Conry-Cantilena C, Cantilena LR Jr, Wang Y, Levine M. Pharmacokinetic model of ascorbic acid in healthy male volunteers during depletion and repletion. Pharm Res. 1997;14(9):1133-9.

20. Bachar M, Raimann JG, Kotanko P. Impulsive mathematical modeling of ascorbic acid metabolism in healthy subjects. J Theor Biol. 2016;392:35-47.

21. Bothwell TH, Bradlow BA, Jacobs P, Keeley K, Kramer S, Seftel H, Zail S. Iron metabolism in scurvy with special reference to erythropoiesis. $\mathrm{Br} J$ Haematol. 1964;10:50-8.

22. Sirover WD, Siddiqui AA, Benz RL. Beneficial hematologic effects of daily oral ascorbic acid therapy in ESRD patients with anemia and abnormal iron homeostasis: a preliminary study. Ren Fail. 2008;30(9):884-9.

23. Attallah N, Osman-Malik Y, Frinak S, Besarab A. Effect of intravenous ascorbic acid in hemodialysis patients with EPO-hyporesponsive anemia and hyperferritinemia. Am J Kidney Dis. 2006;47(4):644-54.

24. Deira J, Diego J, Martinez R, Oyarbide A, Gonzalez A, Diaz H, Grande J. Comparative study of intravenous ascorbic acid versus low-dose desferroxamine in patients on hemodialysis with hyperferritinemia. J Nephrol. 2003;16(5):703-9. 
25. Giancaspro V, Nuzziello M, Pallotta G, Sacchetti A, Petrarulo F. Intravenous ascorbic acid in hemodialysis patients with functional iron deficiency: a clinical trial. J Nephrol. 2000;13(6):444-9.

26. Keven K, Kutlay S, Nergizoglu G, Erturk S. Randomized, crossover study of the effect of vitamin C on EPO response in hemodialysis patients. Am J Kidney Dis. 2003;41(6):1233-9.

27. Sezer S, Ozdemir FN, Yakupoglu U, Arat Z, Turan M, Haberal M. Intravenous ascorbic acid administration for erythropoietin-hyporesponsive anemia in iron loaded hemodialysis patients. Artif Organs. 2002;26(4):366-70.

28. Seibert E, Richter A, Kuhlmann MK, Wang S, Levin NW, Kotanko P, Handelman GJ. Plasma vitamin C levels in ESRD patients and occurrence of hypochromic erythrocytes. Hemodialysis international International Symposium on Home Hemodialysis. 2017;21(2):250-5.

29. Deved V, Poyah P, James MT, Tonelli M, Manns BJ, Walsh M, Hemmelgarn BR. Ascorbic acid for anemia management in hemodialysis patients: a systematic review and meta-analysis. Am J Kidney Dis. 2009; 54(6):1089-97.

30. McCauley LK, Koh AJ, Beecher CA, Cui Y, Rosol TJ, Franceschi RT. PTH/PTHrP receptor is temporally regulated during osteoblast differentiation and is associated with collagen synthesis. J Cell Biochem. 1996;61(4):638-47.

31. Friedman PA, Coutermarsh BA, Kennedy SM, Gesek FA. Parathyroid hormone stimulation of calcium transport is mediated by dual signaling mechanisms involving protein kinase a and protein kinase C. Endocrinology. 1996;137(1):13-20.

32. Pearce SH, Thakker RV. The calcium-sensing receptor: insights into extracellular calcium homeostasis in health and disease. J Endocrinol. 1997; 154(3):371-8

33. Abuelo JG, Schwartz ST, Reginato AJ. Cutaneous oxalosis after long-term hemodialysis. Arch Intern Med. 1992;152(7):1517-20.

34. Hoffman GS, Schumacher HR, Paul H, Cherian V, Reed R, Ramsay AG, Franck WA. Calcium oxalate microcrystalline-associated arthritis in end-stage renal disease. Ann Intern Med. 1982;97(1):36-42.

35. Salyer WR, Hutchins GM. Cardiac lesions in secondary oxalosis. Arch Intern Med. 1974;134(2):250-2.

36. Salyer WR, Keren D. Oxalosis as a complication of chronic renal failure Kidney Int. 1973;4(1):61-6.

37. Wells CG, Johnson RJ, Qingli L, Bunt-Milam AH, Kalina RE. Retinal oxalosis. A clinicopathologic report. Arch Ophthalmol. 1989;107(11):1638-43.

38. Zazgornik J, Balcke P, Rokitansky A, Schmidt P, Kopsa H, Minar E, Graninge W. Excessive myocardial calcinosis in a chronic hemodialyzed patient. Klin Wochenschr. 1987;65(2):97-100

Ready to submit your research? Choose BMC and benefit from:

- fast, convenient online submission

- thorough peer review by experienced researchers in your field

- rapid publication on acceptance

- support for research data, including large and complex data types

- gold Open Access which fosters wider collaboration and increased citations

- maximum visibility for your research: over $100 \mathrm{M}$ website views per year

At $\mathrm{BMC}$, research is always in progress.

Learn more biomedcentral.com/submissions 